\title{
Mediation Role of Service Capabilities in Supply Chain Integration on Supply Chain Performance in Small and Medium Enterprises
}

\author{
Dorina Widowati ${ }^{1}$, Ratna Darasih ${ }^{2}$, Nuzul Ramadhani ${ }^{3}$ \\ \{dorina.widowati@trisakti.ac.id ${ }^{1}$, ratna.darasih@trisakti.ac.id², nuzulramadhaninuzul@gmail.com ${ }^{3}$ \} \\ Universitas Trisakti, Jakarta, Indonesia
}

\begin{abstract}
The research objective is to analyze the effect of supply chain integration on supply chain performance mediated by service capabilities. Data samples were taken by 250 SME owners in the Jabodetabek (Jakarta, Bogor, Depok, Bekasi) area using Google forms. The data used is cross sectional and the approach used is structured equation modeling. The results of this study are Supply Integration has an effect on Service Capabilities (service reliability, service feasibility, service efficiency, added value), Service Capabilities (service reliability, service flexibility, service efficiency, added value) affect Supply Chain performance and Supply Chain Integration has an effect on supply chain performance mediated by Service Capabilities (service reliability, service ability, service efficiency, added value). In conclusion, in SMEs the role of Service Capabilities (service reliability, service flexibility, service efficiency, added value) in supply chain integration on chain performance supply is done.
\end{abstract}

Keywords: Supply Chain Integration; Service Capabilities; Supply Chain Performance; Small and Medium Enterprises

\section{Introduction}

In the current conditions, small and medium enterprises (SMEs) face competition with foreign companies in terms of price, quality, speed of product innovation. Another thing is that the Covid 19 Pandemic makes it worse, for that SMEs must have a competitive advantage in order to survive in the market, one of which is in terms of supply chain activities. Supply Chain Management is a prominent field of science in giving companies to form a competitive advantage in the long term [1] Integrative organizational collaboration improves organizational performance (green et al., 2006; Tracey and Tan, 2001) and supply chain performance (Gunasekaran et al., 2004; Otto and Kotzab, 2003). Integration in the supply chain is required in improving supply chain performance.

Supply chain integration which is a collaboration strategy of bothinternal and external factors of the company which includes the supportof managers, coordination between departments / sections, information technology, goal congruence, and communication collaboration will affect the performance of the supply chain. The benefits of Supply Chain Integration must be applicable into service capabilities assessed by consumers such as service 
reliability (Lu, 2007), Service Flexibility (Rozenzweig et al., 2003; Holweg et al, 2005), Service Efficiency (Kogut and Zander, 2003), and Value Added Service (notteboom, 2004; Wang and Cullinane, 2006) because this capability is able to develop a valuable and special superiority advantage (Barney et al., 2001). Research from [2], examines the role of supply chain integration in improving supply chain performance. Research [3], examined that supply chain integration is applied in service capabilities because these capabilities are able to develop a valuable competitive advantage.

\section{Literature Review}

\subsection{Supply Chain Integration}

Supply Chain Integration is a strategic alliance with supply chain partners. The organization's internal and external collaborative management processes establish and maintain a seamless channel for the timely movement of materials, finished goods, information, decisions and services to end consumers. [4], [5]Supply chain integration requires strategic relationships with supplier chain partners [6]. In particular, supply chain integration involves collaboration between focus firms and their customers and suppliers in managing business boundary expansion activities, including collaboration in purchasing, planning and forecasting and joint product development [7].

Supply chain integration is the company's ability to manage both intra and interorganization to achieve efficient flow of products, services, information and money [8] . This refers to the company's expertise in strategically collaborating with its supplier partners and co-operatives in managing processes to manage maximum value to customers at minimal cost [9], according to [10] the most important goal of Supply Chain Integration is to obtain effective and efficient transfer of products, services, information, money, and decisions through coordinated efforts, and the exchange of information with the aim of providing the best value to consumers at a low cost without hindrance. Supply Chain integration in the company is very important to build mutual trust with other companies, can focus more on managing relationships and more easily get the information needed both from inside and outside the company.

\subsection{Service Capabilities}

Supply chain service capabilities are the result of a combination of the attempt of entire external and internal partners of the supply chain that refers to the capability of the whole supply chain to recognize, utilize and comprehend resources, skills and accumulated internal and external knowledge of the organization to facilitate and add value to all supply chain service activities more efficiently, flexibly and reliablely. [4], [5]

The Supply Chain Capabilties Service results from the synergy of entire external and internal partners of the supply chain and refers to the capability of the whole supply chain to recognize, utilize, and comprehend the two extra and intra-organizational assets, expertise, and assembled knowledge to ease and add value to be efficient, flexible and reliable in all supply chain service activities. We propose that a highly integrated supply chain makes it possible to build different services capabilities (capabilities) in four areas of the supply chain: Service Reliability (Reliability of services), Service Flexibility (Service Flexibility), Service Effciency (Service Efficiency), and Value Added (ValueAdded). Companies that implement 
integration on the supply chain and utilize it to create Service Capabilties supply chain that represent a high level of organizational capability. [3].

\subsection{Supply Chain Performance}

Supply Chain Performance is a process to see how effective and efficient a systematic supply chain activity (Anand and Grover, 2015). Companies and suppliers involved in supplying raw materials and equipment, producing goods, or delivering them to end customers are a physical network of supply chain performance [11]. Zaroni (2017) stated that increasing competitive advantage through the efficiency of distribution and production costs and the accuracy of product quality to the end customer is an effective and efficient supply chain performance. Supply chain performance has the goal of maximizing value to end customers [12] Good supply chain performance will create more targeted companies and good profits for suppliers, agents, and end customers [13]. In the performance of the supply chain the priority is to maintain the quality and timeliness of delivery, which is important because it concerns consumer confidence [14]. [15] emphasized that those involved in the performance of the supply chain which is a company with similar interests, namely: Suppliers, Manufactures, Distribution, Retail Outlet, Customers.

According to Veera and Chandran (2016), indicators of supply chain performance measurement are accuracy of financing, the coordination of parts, suppliers, monsumen and increased sales. If a company's supply chain performance is effective and efficient compared to other companies it will be a source of competitive advantage for the company [16].

\subsection{Understanding MSMEs/SME}

MSMEs (Micro, Small and Medium Enterprises) According to Law no. 20 of 2008: Microenterprises are individual-owned businesses and/or individual productive business entities in accordance with the requirements of Micro-enterprises as regulated in this Law. Maximum turnover of IDR 300 million per year and Maximum assets owned IDR 50 million (excluding land and buildings of business premises). Small Business is a stand-alone productive economic venture, conducted by individuals or business entities that are not subsidiaries or are not branches of companies owned, controlled, or become part of either directly or indirectly from Medium Enterprises or Large Businesses that meet the criteria of Small Businesses as referred to in this Law. maximum turnover of more than IDR 300 million - IDR 2.5 billion per year and Assets of more than IDR 50 million - IDR 500 million (excluding land and buildings for business)

\subsection{Conceptual Framework}

Supply chain integration which is a collaboration strategy of both internal and external factors of the company which includes the support of top managers, coordination between departments / parts, information technology, goal congruence, and communication collaboration will affect the performance of the supply chain. The benefits of Supply Chain Integration must be applicable into service capabilities assessed by consumers such as service reliability (Lu, 2007), Service Flexibility (Rozenzweig et al., 2003; Holweg et al, 2005), Service Efficiency (Kogut and Zander, 2003), and Value Added Service (notteboom, 2004; Wang and Cullinane, 2006) because this capability is able to develop a valuable and special 
superiority advantage (Barney et al., 2001). For that can be made conceptual framework image as follows:

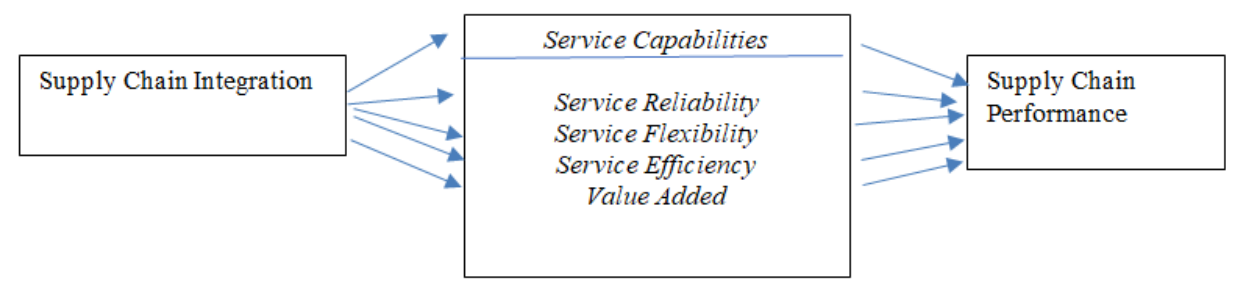

Fig. 1. Conceptual Framework

\subsection{Development of Hypotheses}

Previous research (Bagchi and Skjoett-Larsen, 2005; Fabble Costes and Jahre, 2007,2008; Horvaerth, 2001; Wisner, 2003; Kim, 2006; Power, 2005) concluded that the success of a company and its supply chain depends on its supply chain integration. . But despite its importance, supply chain integration is only newly researched [4]. the most intensive level of strategic Alliance is Supply Chain Integration (Simchi-Levi et al, 2003; Kim, 2006). increased value of goods and services, market entry, strong operations, technological and enterprise skills caused by strategic alliances (Simchi-Levi et al. , 2003). Therefore it is possible that supply chain integration may be related to service capabilities. Supply chain integration has been proposed to improve customer response in service capabilities, and barriers to functions or organizations are eliminated, thus leading to efficient relationships in service capabilities and strengthening the competitiveness of service capabilities. Stevens, 1990). From the literature above, the following hypothesis can be drawn:

a. Hypothesis 1: Supply chain integration affects service capabilities

b. Hypothesis 2: Supply chain integration affects service reliability

c. Hypothesis 3: Supply chain integration affects service flexibility

d. Hypothesis 4: Supply chain integration affects service efficiency

e. Hypothesis 5: Supply chain integration affects value added

Previous research (Flynn and Flynn, 1999) conclude that the company's performance, both individually and/or with other capabilities, is due to a positive contribution from efficiency, reliability, and flexibility . the competitive capability of manufacturing strategies from conventional policies results in increased company survival and growth. 1. (Rosenzweig et al, 2003). Achieving customer satisfaction is related to Competitive Ability, Marketing performance (Kim, 2006), and general performance. From the literature above, the following hypothesis can be drawn:

a. Hypothesis 6: Service Capabilities affect supply chain performance

b. Hypothesis 7: Service Reliability affects Supply Chain Performance

c. Hypothesis 8: Service Flexibility affects Supply Chain Performance

d. Hypothesis 9: Service Efficiency affects Supply Chain Performance

e. Hypothesis 10: Value added affects Supply Chain Performance

Supply Chain Management is a prominent field of science in giving companies to form a competitive advantage in the long run (Azadi et al., 2014). Integrative organizational collaboration improves organizational performance (green et al., 2006; Tracey and Tan, 2001) and supply chain performance (Gunasekaran et al., 2004; Otto and Kotzab, 2003). Integration in the supply chain is necessary in improving supply chain performance. Supply chain 
integration which is a collaboration strategy of both internal and external factors of the company which includes support of pucak manajaer, coordination between departments / parts, information technology, goal congruence, and communication collaboration will affect the performance ofthe supply chain.

The benefits of Supply Chain Integration should be applicable into service capabilities assessed by consumers such as service reliability (Lu, 2007), Service Flexibility (Rozenzweig et al., 2003; Holweg et al, 2005), Service Efficiency (Kogut and Zander, 2003), and Value Added Service (notteboom, 2004; Wang and Cullinane, 2006) because this capability is able to develop a valuable and special superiority advantage (Barney et al., 2001) From the literature above it can be drawn the following hypothesis:

a. Hypothesis 11: Supply chain integration affects supply chain performance through service capabilities

b. Hypothesis 12: Supply chain integration affects supply chain performance through service reliability

c. Hypothesis 13: Supply chain integration affects supply chain performance through service flexibility

d. Hypothesis 14: Supply chain integration affects supply chain performance through service efficiency

e. Hypothesis 15: Supply chain integration affects supply chain performance through Value added

\subsection{Research Methodology}

This study refers to previous research conducted by Veera Pandiyan Kaliani Sundram, V.G.R. Chandran, and Muhammad Awais Bhatti (2016), [3]. Based on the purpose of the design research used in this study is the testing of hypotheses that have the goal of explaining certain relationships, establishing differences between groups of two or more factors in the situation [17]. The hypothesis test was conducted to check the effect of Supply Chain Integration on Supply Chain Performance through Service Capabilities on SMEs.

The data that will be used in this study is cross sectional data because data collection is done by doing one collection with a daily, weekly, monthly period in answering research questions [17].In this study, the analysis unit was addressed to individuals, namely SME owners in the Jabodetabek region by spreading questionnaires as many as 250 SMEs. In this study, the three variables were measured using the Interval Scale, which is used to give numbers, have levels, and have distances. The type of interval scale used in this study is the Likert scale, which uses 5 scales namely:

$1=$ Strongly Disagree

$2=$ Disagree

$3=$ Simply Agree

$4=$ Agree

$5=$ Very Agree

Table 1. Validity Test Results on Supply Chain Integration Variables

\begin{tabular}{|c|c|c|}
\hline Indicators & Loading Factor Value & Decision \\
\hline In the supply chain, SMEs often make contact with each other. & .587 & Valid \\
\hline Insupply,SMEs often make contact with each other. & .739 & Valid \\
\hline $\begin{array}{l}\text { SMEs extend their supply chains beyond existing } \\
\text { consumers/suppliers. }\end{array}$ & 697 & Valid \\
\hline SMEs participate in marketing efforts to their consumers & .494 & Valid \\
\hline
\end{tabular}

Source: Data Processing Results Using Amos version 24 
Table 2. Validity Test Results on Service Capabilities Variables

\begin{tabular}{|c|c|c|}
\hline $\begin{array}{l}\text { Indicators } \\
\end{array}$ & Loading Factor Value & Decision \\
\hline $\begin{array}{l}\text { SMEs and suppliers offer reliability by providing booking } \\
\text { space }\end{array}$ & .471 & Valid \\
\hline SMEs and suppliers offer reliability by scheduling advertising & .659 & Valid \\
\hline SMEs and suppliers offer accurate documentation & .703 & Valid \\
\hline SMEs and suppliers offer shipping security & .581 & Valid \\
\hline SMEs and suppliers offer varied delivery services & .588 & Valid \\
\hline $\begin{array}{l}\text { SMEs and suppliers are more flexible in meeting different } \\
\text { consumer needs }\end{array}$ & .671 & Valid \\
\hline SMEs and suppliers have a good response to consumers & .612 & Valid \\
\hline $\begin{array}{l}\text { SMEs and suppliers are able to make adjustments in relation } \\
\text { to addressing market changes }\end{array}$ & .472 & Valid \\
\hline SMEs and suppliers better meet approvals for cost per unit & .496 & Valid \\
\hline SMEs and suppliers meet productivity standards, better & .685 & Valid \\
\hline SMEs and suppliers meet timely delivery of needs, better & .689 & Valid \\
\hline SMEs and suppliers have a need for shorter waiting times & .527 & Valid \\
\hline $\begin{array}{l}\text { SMEs and suppliers have the ability to provide warehouse } \\
\text { services }\end{array}$ & .673 & Valid \\
\hline $\begin{array}{l}\text { SMEs and suppliers have the ability to provide customs } \\
\text { service permits }\end{array}$ & .688 & Valid \\
\hline $\begin{array}{l}\text { SMEs and suppliers have the ability to provide multi-modal } \\
\text { services }\end{array}$ & .699 & Valid \\
\hline SMEs and suppliers own the ability to provide stump services & .521 & Valid \\
\hline
\end{tabular}

Source: Data Processing Results Using Amos version 24

Table 3. Validity Test Results on Supply Chain Performance Variables

\begin{tabular}{|c|c|c|}
\hline Indicators & Loading Factor Value & Decision \\
\hline Accuracy of financing & .556 & Valid \\
\hline Increased coordination between parts & 647 & Valid \\
\hline Increased coordination between suppliers & .755 & Valid \\
\hline Increased coordination between consumers & .764 & Valid \\
\hline Increased sales & .675 & Valid \\
\hline
\end{tabular}

Source: Data Processing Results Using Amos version 24

In tables 1, 2 and 3 show that all variable statement items of Supply ChainIntegration, Service Capabilities and Supply Chain Performance have a factor loading value of $\geq 0.40$ which means each statement item used to measure those variables is declared precise and feasible so that these supply chain integration variables, service capabilities and Supply Chain Performance can be researched.

Table 4. Reliability Test Results

\begin{tabular}{clccc}
\hline No. & Variables/Dimensions & Cronbach's Alpha & Items & Information \\
\hline 1 & Supply Chain Integration & .717 & 4 & Reliable \\
2 & Service Reliabilities & .713 & 4 & Reliable \\
3 & Service Flexibilities & .658 & 4 & Reliable \\
4 & Service Efficiencies & .699 & 4 & Reliable \\
5 & Value Added & .707 & 4 & Reliable \\
6 & Supply Chain Performance & .809 & 5 & Reliable \\
\hline
\end{tabular}

Source: Data Processing Results Using Amos version 24 
In table 4 above, cronbach's Alpha value is seen as a result of reliability tests of existing instruments in the variables of Supply Chain Integration, Service Capabilities and Supply Chain Performance. The results showed that all instruments present on each variable had a Cronbach's Alpha value greater than 0.6 which means all instruments used in the research variable are reliable.

Table 5. Goodness of Fit Model Test Results

\begin{tabular}{|c|c|c|c|c|}
\hline $\begin{array}{c}\text { Kind } \\
\text { Measurement }\end{array}$ & Measurement & Value & Recommended acceptance limits & Conclusion \\
\hline Absolute fit & P-value & 0.000 & $\geq 0.05$ & Poor fit \\
\hline \multirow[t]{2}{*}{ measures } & ECVI & 2.473 & $\begin{array}{l}\text { Close to Saturated value than } \\
\text { independent }(2,915)\end{array}$ & Goodness of fit \\
\hline & RMSEA & .058 & $\leq 0.1$ & Goodness of fit \\
\hline Incremental & IFI & 0.871 & $\geq 0.90$ or close to 1 & Marginal fit \\
\hline \multirow[t]{4}{*}{ fit measures } & NFI & 0.754 & $\geq 0.90$ or close to 1 & Poor fit \\
\hline & TLI & 0.856 & $\geq 0.90$ or close to 1 & Marginal fit \\
\hline & CFI & 0.869 & $\geq 0.90$ or close to 1 & Marginal fit \\
\hline & RFI & 0.729 & $\geq 0.90$ or close to 1 & Poor fit \\
\hline Parsimonius & CMIN/DF & 1,828 & Lower limit 1, upper limit 5 & Goodness of fit \\
\hline fit measure & AIC & 603.299 & $\begin{array}{l}\text { Close to Saturated value than } \\
\text { independent }(650,000)\end{array}$ & Goodness of fit \\
\hline
\end{tabular}

Source: Data Processing Results Using Amos version 24

The results of the feasibility assessment of the above model with the approach of Absolute Fit Measures and Parsimonious Fit Measures resulted in the conclusion of goodness of fit. So the model test is said to be feasible to proceed to the next test which is hypothesis testing.

\section{Results and Discussions}

The test was conducted using structural equation model (SEM) analysis. Here are the results of hypothesis testing:

Table 6. Hypothesis Test Results 1-5

\begin{tabular}{lccc}
\hline \multicolumn{1}{c}{ Hypothesis } & Estimate ( $\beta)$ & p-value & Decision \\
\hline H1: Supply Chain Integration affects Service Capabilities & 0.470 & 0.000 & $\begin{array}{c}\text { Ho rejected } \\
\text { Ha accepted } \\
\text { Ho rejected }\end{array}$ \\
H2: Supply Chain Integration affects Service Reliability. & 0.701 & 0.000 & $\begin{array}{c}\text { Ha accepted } \\
\text { Ho rejected }\end{array}$ \\
H3: Supply Chain Integration affects Service Flexibility. & 0.534 & 0.000 & $\begin{array}{c}\text { Ha accepted } \\
\text { Ho rejected }\end{array}$ \\
H4: Supply Chain Integration affects Service Efficiency. & 0.434 & 0.000 & $\begin{array}{c}\text { Ha accepted } \\
\text { Ho rejected } \\
\text { Ha accepted }\end{array}$ \\
H 5: Supply Chain Integration affects Value Added & 0.664 & 0.000 &
\end{tabular}

Based on table 6 , hypothesis one shows a p-value of 0.000 smaller than 0.05 and a positive estimate value of 0.470 . The conclusion that can be drawn from the results of the hypothesis test that Ho was rejected and Ha accepted and statistically with a 95\% confidence level there 
is an influence on Supply Chain Integration on Service Capabilities. This explains that SMEs have integrated their supply chains well such as contacts, communication and systems that are in accordance with their suppliers so as to improve the Service Capabilities of SMEs in performing reliable, flexible, efficient and providing added value.

The second hypothesis shows a p-value of 0.000 smaller than 0.05 and an estimate value of 0.701 . The conclusion that can be drawn from the results of the hypothesis test that Ho was rejected and Ha was accepted and statistically with a 95\% confidence level there is an effect of supply chain integration on service reliability.

This explains that SMEs have implemented their supply chain integration well so as to improve service reliability in offering accurate information, shipping security, ad scheduling.

The third hypothesis shows a p-value of 0.000 smaller than 0.05 and a positive estimate value of 0.534 . The conclusion that can be drawn from the results of the hypothesis test that Ho was rejected and $\mathrm{Ha}$ accepted and statistically with a $95 \%$ confidence level there is an effect of supply chain integration on service flexibility.

This explains that SMEs have integrated their supply chains well such as contacts, communication and systems that are in accordance with their suppliers so as to improve the Service Flexibility of SMEs in offering varied delivery services, meeting consumer demand, good response and easy to adjust to market changes.

The fourth hypothesis shows $a p$-value of 0.000 smaller than 0.05 and an estimate value of 0.434 . The conclusion that can be drawn from the results of the hypothesis test that Ho was rejected and Ha was accepted and statistically with a confidence level of $95 \%$ there is an influence of supply chain integration on service efficiency.

This explains that SMEs have implemented their supply chain integration well so as to improve Service Efficiency in meeting production standards, on-time delivery, shorter waiting times.

The fifth hypothesis shows a p-value of 0.000 smaller than 0.05 and a positive estimate value of 0.664 . The conclusion that can be drawn from the results of the hypothesis test that Ho was rejected and Ha accepted and statistically with a $95 \%$ confidence level there is an influence of supply chain integration on Value Added. This explains that SMEs have done their supply chain integration well such as contacts, communication and systems that are in accordance with their suppliers so as to increase the Value Added (Value Added) of SMEs in offering door-to-door services, stock (inventory), multimodal (more than two types of modes of transportation).

Table 7. Hypothesis Test Results 6-10

\begin{tabular}{|c|c|c|c|}
\hline Hypothesis & Estimate $(\beta)$ & p-value & Decision \\
\hline H6: Service Capabilities affect Supply Chain Performance & 1.235 & 0.000 & $\begin{array}{l}\text { Ho rejected } \\
\text { Ha accepted }\end{array}$ \\
\hline H7: Service Reliability affect Supply Chain Performance & 0.381 & 0.001 & $\begin{array}{l}\text { Ho rejected } \\
\text { Ha accepted }\end{array}$ \\
\hline H 8: Service Flexibility affect Supply Chain Performance & 0.221 & 0.008 & $\begin{array}{l}\text { Ho rejected } \\
\text { Ha accepted }\end{array}$ \\
\hline H9: Service Efficiency affect Supply Chain Performance & 0.367 & 0.000 & $\begin{array}{l}\text { Ho rejected } \\
\text { Ha accepted }\end{array}$ \\
\hline $\begin{array}{l}\text { H 10: Value Added influence on supply chain } \\
\text { performance }\end{array}$ & 0.187 & 0.016 & $\begin{array}{l}\text { Ho rejected } \\
\text { Ha accepted }\end{array}$ \\
\hline
\end{tabular}

Source: Data results (AMOS) 
Based on table 7, the sixth hypothesis shows p-value of 0.000 smaller than 0.05 and a positive estimate value of 1.235 . The conclusion that can be drawn from the results of the hypothesis test that Ho was rejected and Ha accepted and statistically with a confidence level of $95 \%$ service capabilities affect supply chain performance.

This explains that SMEs have done their Service Capabilities in performing reliable, flexible, efficient and provide added value so as to enhance the performance of the SME supply chain in coordination with suppliers, consumers, increased sales, more accurate calculations.

The seventh hypothesis shows a p-value of 0.001 smaller than 0.05 and a positive estimate value of 0.381 . The conclusion that can be drawn from the results of the hypothesis test that Ho was rejected and $\mathrm{Ha}$ accepted and statistically with a confidence level of $95 \%$ Service Reliability affect supply chain performance.

This explains that SMEs have implemented service reliability in offering accurate information, shipping security, advertising scheduling so as to enhance the performance of the SME supply chain in coordination with suppliers, consumers, increased sales, more accurate calculations.

The eighth hypothesis shows a p-value of 0.008 smaller than 0.05 and an estimate value of 0.221 . The conclusion that can be drawn from the results of the hypothesis test that Ho was rejected and Ha accepted and statistically with a confidence level of 95\% Service Flexibility affect Supply Chain Performance.

This explains that SMEs have conducted Service Flexibility in offering varied delivery services, meeting consumer demand, good response and easy to adjust to market changes so as to enhance the performance of the SME supply chain in coordination with suppliers, consumers, increased sales, more accurate calculations.

The ninth hypothesis shows $a$ p-value of 0.000 smaller than 0.05 and an estimate value of 0.367. The conclusion that can be drawn from the results of the hypothesis test that Ho was rejected and Ha accepted and statistically with a confidence level of 95\% Service Efficiency affect Supply Chain Performance.

This explains that SMEs have implemented Service Efficiency in meeting production standards, timely delivery, shorter waiting times thus enhancing the performance of the SME supply chain in coordination with suppliers, consumers, increased sales, more accurate calculations.

The tenth hypothesis shows a p-value of 0.016 smaller than 0.05 and an estimate value of 0.187. The conclusion that can be drawn from the results of the hypothesis test that Ho was rejected and Ha accepted and statistically with a confidence level of 95\% Value Added affect the Performance of the Supply chain.

This explains that SMEs have done Value Added in offering door-to-door, stock (inventory), multimodal (more than two types of modes of transportation) thus enhancing the performance of the SME supply chain in coordination with suppliers, consumers, increased sales, more accurate calculations.

Based on Baron and Kenny's stages, Service Capabilities can be a mediation variable if the following conditions are met: 
Table 8. Hypothesis Test Results 11

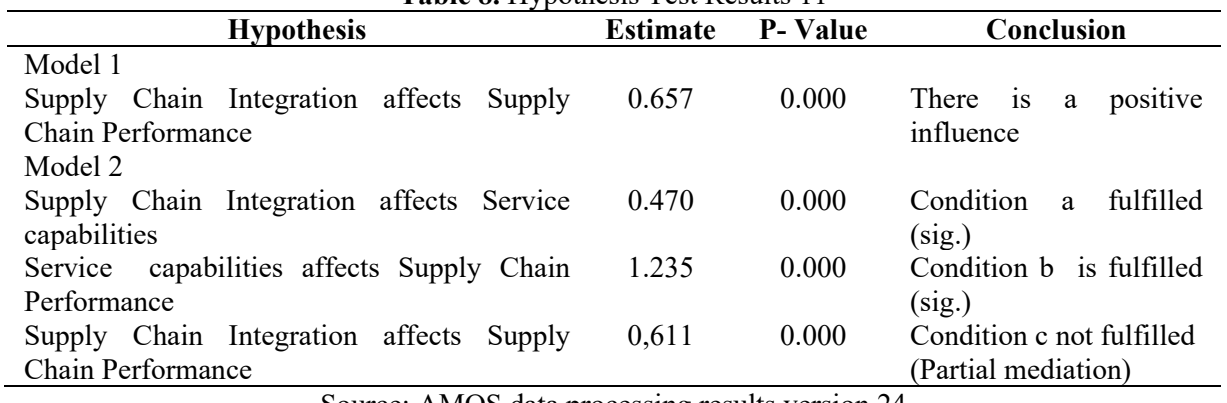

Source: AMOS data processing results version 24

Based on table 8,hypothesis eleven indicates service capabilities are capable of mediating supply chain integration and supply chain performance with an estimated value of 0.611 . The conclusion that can be drawn from the results of the hypothesis test that Ho was rejected and Ha was accepted and statistically with a confidence level of 95\% Supply Chain Integration affects Supply Chain Performance through service capabilities.

This explains that SMEs have integrated their supply chains well such as contacts, communication and systems that are in accordance with their suppliers so as to enhance the performance of the SME supply chain in coordination with suppliers, consumers, increased sales, more accurate calculations by performing Service Capabilities in the form of performing reliable, flexible, efficient and providing added value.

Table 9. Hypothesis Test Results 12

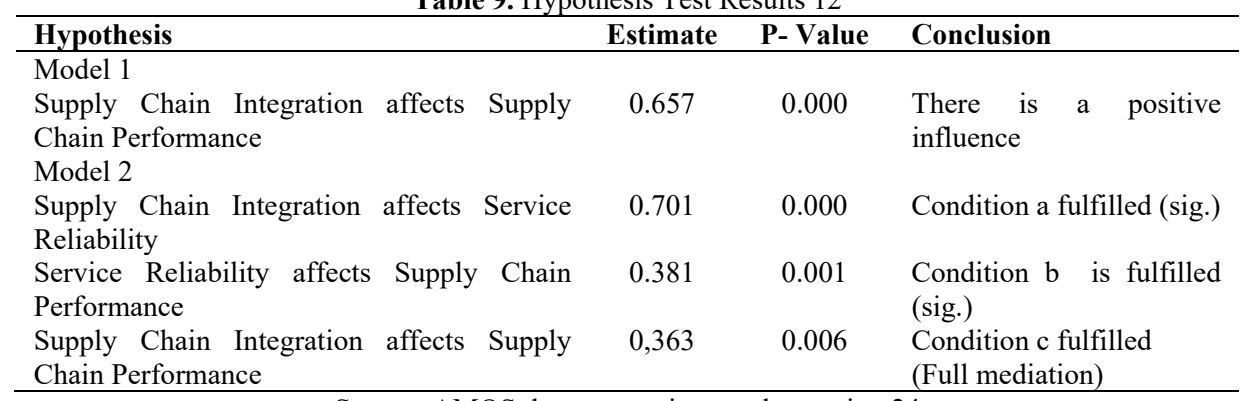

Source: AMOS data processing results version 24

Based on table 9, the twelfth hypothesis indicates service reliability is capable of mediating supply chain integration and supply chain performance with an estimate of 0.363 . The conclusion that can be drawn from the results of the hypothesis test that Ho was rejected and $\mathrm{Ha}$ accepted and statistically with a confidence level of 95\% Supply Chain Integration affect Supply Chain Performance (KRP) through Service Reliability.

This explains that SMEs have implemented good supply chain integration such as contacts, communications and systems that are in accordance with their suppliers so as to improve the performance of the SME supply chain in coordination with suppliers, consumers, increased sales, more accurate calculations by applying service reliability in offering accurate information, shipping security, advertising scheduling. 
Table 10. Hypothesis Test Results 13

\begin{tabular}{|c|c|c|c|}
\hline Hypothesis & Estimate & P-Value & Conclusion \\
\hline $\begin{array}{l}\text { Model } 1 \\
\text { Supply Chain Integration affects Supply } \\
\text { Chain Performance }\end{array}$ & 0.657 & 0.000 & $\begin{array}{l}\text { There is a positive } \\
\text { influence }\end{array}$ \\
\hline $\begin{array}{l}\text { Model } 2 \\
\text { Supply Chain Integration affects Service } \\
\text { Flexibility }\end{array}$ & 0.534 & 0.000 & Condition a fulfilled (sig.) \\
\hline $\begin{array}{l}\text { Service Flexibility affects Supply Chain } \\
\text { Performance }\end{array}$ & 0.221 & 0.008 & $\begin{array}{l}\text { Condition b is fulfilled } \\
\text { (sig.) }\end{array}$ \\
\hline $\begin{array}{l}\text { Supply Chain Integration affects Supply } \\
\text { Chain Performance }\end{array}$ & 0,517 & 0.000 & $\begin{array}{l}\text { Condition c fulfilled } \\
\text { (Full mediation) }\end{array}$ \\
\hline
\end{tabular}

Source: AMOS data processing results version 24

Based on table 10, the thirteenth hypothesis indicates service flexibility is capable of mediation supply chain integration and supply chain performance with an estimate of 0.517 . The conclusion that can be drawn from the results of the hypothesis test that Ho was rejected and $\mathrm{Ha}$ accepted and statistically with a confidence level of $95 \%$ there is an influence of Supply Chain Integration on Supply Chain Performance (KRP) through Service Flexibility.

This explains that SMEs have implemented good supply chain integration like contacts, communication and systems that are in accordance with their suppliers so as to enhance the performance of the SME supply chain in coordination with suppliers, consumers, increased sales, more accurate calculations by applying Service Flexibility in offering varied delivery services, meeting consumer demand, good response and easily adjusting to market changes.

Table 11. Hypothesis Test Results 14

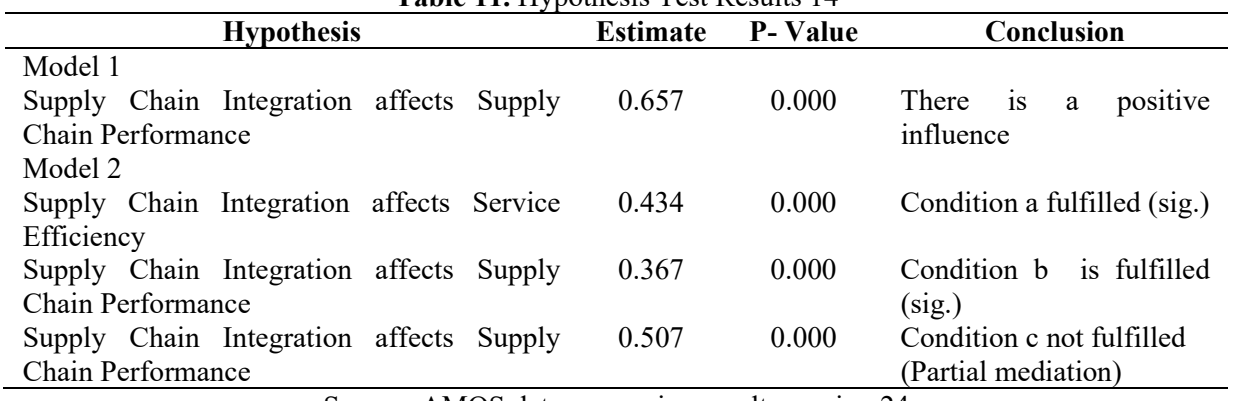

Source: AMOS data processing results version 24

Based table 11 The fourteenth hypothesis shows that service efficiency is capable of mediation supply chain integration and supply chain performance with an estimate of 0.507 . The conclusion that can be drawn from the results of the hypothesis test that Ho was rejected and $\mathrm{Ha}$ accepted and statistically with a confidence level of $95 \%$ Supply Chain Integration affect Supply Chain Performance (KRP) through Service Efficiency.

This explains that SMEs have integrated their supply chains well such as contacts, communications and systems that are in accordance with their suppliers so as to enhance the performance of the SME supply chain in coordination with suppliers, consumers, increased sales, more accurate calculations by applying Service Efficiency in meeting production standards, on-time delivery, shorter waiting times. 
Table 12. Hypothesis Test Results 15

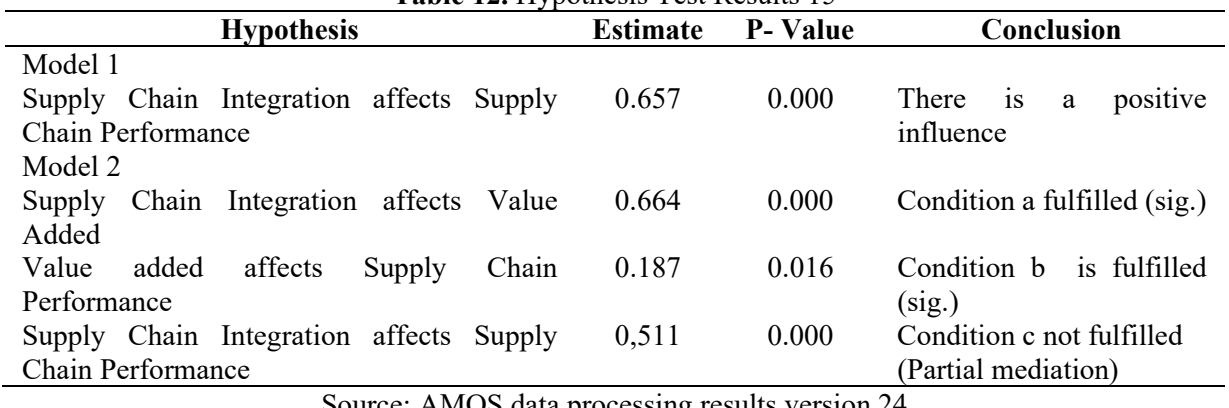

Source: AMOS data processing results version 24

Based on table 12, the fifteenth hypothesis indicates value added is capable of mediating supply chain integration and supply chain performance with an estimate of 0.511 . The conclusion that can be drawn from the results of the hypothesis test that Ho was rejected and Ha accepted and statistically with a confidence level of $95 \%$ there is an influence of Supply Chain Integration on Supply Chain Performance (KRP) through Value Added.

This explains that SMEs have implemented good supply chain integration such as contacts, communication and systems that are in accordance with their suppliers so as to enhance the performance of the SME supply chain in coordination with suppliers, consumers, increased sales, more accurate calculations by providing Value Added in offering door-to-door services, stock (inventory), multimodal (more than two types of modes of transportation).

\section{Conclusions}

This research aims to analyze the effect of Supply Chain Integration on Supply Chain Performance mediated by Service Capabilities (Service Reliability, Service Flexibility Service Efficiency, Value Added) in 250 SMEs in Jabodetabek sewilayah. Based on the previous discussion, therefore can be concluded as follows:

There is an influence of Supply Chain Integration on Service Capabilities (Service Reliability, Service Flexibility Service Efficiency, Value Added). This explains that supply chain integration has been implemented that can have an effect on Service Capabilities (Service Reliability, Service Flexibility Service Efficiency, Value Added). So the implementation of supply chain integration in SMEs can improve Service Capabilities (Service Reliability, Service Flexibility Service Efficiency, Value Added).

There is an effect of Service Capabilities (Service Reliability, Service Flexibility Service Efficiency, Value Added) on Supply chain Performance. This explains that Service Capabilities (Service Reliability, Service Flexibility Service Efficiency, Value Added) have been implemented that can have an influence on Supply Chain Performance. So the implementation of Service Capabilities (Service Reliability, Service Flexibility Service Efficiency, Value Added)in SMEs can improve Supply Chain Performance.

There is an influence of Supply Chain Integration on Supply Chain Performance mediated by Service Capabilities (Service Reliability, Service Flexibility Service Efficiency, Value Added). This explains that Supply Chain Integration has been implemented that can have an influence on Supply Chain Performance through Service Capabilities (Service Reliability, Service Flexibility Service Efficiency, Value Added). So the role of Service Capabilities 
(Service Reliability, Service Flexibility Service Efficiency, Value Added) in SMEs can enhance supply chain integration to Supply Chain Performance.

\section{Managerial implications}

SMEs further enhance their supply chain integration by maintaining appropriate contacts, communication and information systems, participation in the marketing of their products so that service capabilities can be improved in reliability, flexibility, efficiency (efficiency) of services and providing value added. SMEs maintain service capabilities with reliability, flexibility, efficiency of service and provide value added so that the execution of the SME supply chain in coordination accompanied by suppliers, consumers, increased sales, more accurate calculations can be maintained.

SMEs maintain supply chain integration by maintaining appropriate contacts, communication and information systems, participation in product marketing so that SME supply chain performance in coordination with suppliers, consumers, increased sales, more accurate calculations can be maintained while maintaining service capabilities with reliability, flexibility, efficiency (efficiency) of services and providing value added.

\section{Acknowledgments}

Thank God for all the blessings and gifts and guidance he has given us all, so that the author can complete a study entitled "THE ROLE OF SERVICE CAPABILITIES MEDIATION ON THE INTEGRATION OF SUPPLY CHAINS TO THE PERFORMANCE OF THE SUPPLY CHAIN". In addition, do not forget the author wants to express his deepest gratitude to various parties who have helped so that this research can be carried out properly. Express of gratitude especially to: Dr. Yolanda Masnita, MM as Dean of the Faculty of Economics and Business trisakti University who has given the opportunity to the author to conduct research, Dr. Sri Vandayuli Riorini, as The Chairperson of the Management Program who continues to motivate his colleagues, Dr. Hj. Husna Leila, as Director of DRPMF and Dr. Jakaria, SE, ME as Ka. DRPMF who has provided input and advice useful for the refinement of this research, and Dra. Ratna Darasih, MM, Nuzul Ramadhani, a member of the research team who has collaborated in completing this research.

\section{References}

[1] M. Azadi, R. F. Saen, and K. H. Zoroufchi, "A new goal-directed benchmarking for supplier selection in the presence of undesirable outputs," Benchmarking An Int. J., vol. 21, no. 3, pp. 314-328, 2014, doi: 10.1108/BIJ-01-2012-0004.

[2] V. P. Kaliani Sundram, V. G. R. Chandran, and M. Awais Bhatti, "Supply chain practices and performance: the indirect effects of supply chain integration," Benchmarking An Int. J., vol. 23, no. 6, pp. 1445-1471, Aug. 2016, doi: 10.1108/BIJ03-2015-0023.

[3] C. S. Yang, "The antecedents and consequences of supply chain service capabilities in the context of container shipping," Int. J. Logist. Manag., vol. 27, no. 2, pp. 236-262, Aug. 2016, doi: 10.1108/IJLM-09-2014-0151.

[4] B. Huo, "The impact of supply chain integration on company performance: an organizational capability perspective," Supply Chain Manag. An Int. J., vol. 17, no. 6, 
pp. 596-610, 2012, doi: 10.1108/13598541211269210.

[5] L. R. Vijayasarathy, "Supply integration: An investigation of its multi-dimensionality and relational antecedents," Int. J. Prod. Econ., vol. 124, no. 2, pp. 489-505, Apr. 2010, doi: 10.1016/J.IJPE.2010.01.010.

[6] M. A. Jacobs, W. Yu, and R. Chavez, "The effect of internal communication and employee satisfaction on supply chain integration," Int. J. Prod. Econ., vol. 171, pp. 60-70, Jan. 2016, doi: 10.1016/J.IJPE.2015.10.015.

[7] W. Yu, M. A. Jacobs, W. D. Salisbury, and H. Enns, "The effects of supply chain integration on customer satisfaction and financial performance: An organizational learning perspective," Int. J. Prod. Econ., vol. 146, no. 1, pp. 346-358, Nov. 2013, doi: 10.1016/J.IJPE.2013.07.023.

[8] H. Y. Lee, Y. J. Seo, and J. Dinwoodie, "Supply chain integration and logistics performance: the role of supply chain dynamism," Int. J. Logist. Manag., vol. 27, no. 3, pp. 668-685, 2016, doi: 10.1108/IJLM-06-2015-0100.

[9] B. B. Flynn, B. Huo, and X. Zhao, "The impact of supply chain integration on performance: A contingency and configuration approach," J. Oper. Manag., vol. 28, no. 1, pp. 58-71, Jan. 2010, doi: 10.1016/J.JOM.2009.06.001.

[10] C. W. Y. Wong, K. Lai, and T. C. E. Cheng, "Value of Information Integration to Supply Chain Management: Roles of Internal and External Contingencies," http://dx.doi.org/10.2753/MIS0742-1222280305, vol. 28, no. 3, pp. 161-200, Jan. 2014, doi: 10.2753/MIS0742-1222280305.

[11] Mubaroq Rayan Muhammad1 Jacky S. B. Sumarauw, "Evaluasi Kinerja Manajemen Rantai Pasok Pada Pemasok Daging Ayam, Jeky Pm," Emba, vol. 2, no. 4, pp. 195202, 2014.

[12] A. Banerjee, B. Sarkar, and S. K. Mukhopadhyay, "Multiple decoupling point paradigms in a global supply chain syndrome: a relational analysis," http://dx.doi.org/10.1080/00207543.2011.588624, vol. 50, no. 11, pp. 3051-3065, Jun. 2012, doi: 10.1080/00207543.2011.588624.

[13] D. Retnonigsih, "THE PERFORMANCE OF APPLE CHIPS SUPPLY CHAIN MANAGEMENT AT SMALL INDUSTRY IN BATU CITY," Agric. SocioEconomics J., vol. 18, no. 2, pp. 70-78, Jul. 2018.

[14] S. C. Wuwung, "MANAJEMEN RANTAI PASOKAN PRODUK CENGKEH PADA DESA WAWONA MINAHASA SELATAN," J. EMBA J. Ris. Ekon. Manajemen, Bisnis dan Akunt., vol. 1, no. 3, pp. 230-238, May 2013, doi: 10.35794/EMBA.1.3.2013.1731.

[15] S. N. Anwar, "Manajemen Rantai Pas Okan (Supply Chain M Anagement) : Konsep Dan Hakikat," J. Din. Inform., vol. 3, no. 2, pp. 1-7, 2011.

[16] E. Soltani, A. Azadegan, Y.-Y. Liao, and P. Phillips, "Quality performance in a global supply chain: finding out the weak link," https://doi.org/10.1080/00207543.2010.508955, vol. 49, no. 1, pp. 269-293, Jan. 2010, doi: $10.1080 / 00207543.2010 .508955$.

[17] U. Sekaran and R. Bougie, "Research Methods For Business: A Skill Building Approach." Wiley, 2016. 